\title{
Sensitivity of East African savannah vegetation to historical moisture-balance variation
}

\author{
I. Ssemmanda ${ }^{1}$, V. Gelorini ${ }^{2}$, and D. Verschuren ${ }^{2}$ \\ ${ }^{1}$ Department of Geology, Makerere University, P.O. Box 7062, Kampala, Uganda \\ ${ }^{2}$ Limnology Unit, Department of Biology, Ghent University, K.L. Ledeganckstraat 35, 9000 Gent, Belgium \\ Correspondence to: D. Verschuren (dirk.verschuren@ugent.be)
}

Received: 23 March 2014 - Published in Clim. Past Discuss.: 11 April 2014

Revised: 23 September 2014 - Accepted: 23 September 2014 - Published: 28 November 2014

\begin{abstract}
Fossil pollen records provide key insight into the sensitivity of terrestrial ecosystems to climate change. However, tracing vegetation response to relatively modest historical climate fluctuations is often complicated by the overriding signature of anthropogenic landscape disturbance. Here we use high-resolution pollen data from a $\sim 200$-year lake-sediment record in open wooded savannah of Queen Elizabeth National Park (southwestern Uganda) to assess the sensitivity of the tropical lowland grassland-forest transition to historical, decade-scale moisture-balance fluctuations. Specifically we trace vegetation response to three episodes of higher average rainfall dated to the $1820 \mathrm{~s}-1830 \mathrm{~s}$, ca. 1865-1890 and from 1962 to around 2000. Our pollen data indeed reveal a sequence of three wet periods, separated by two drier periods. During the inferred wetter episodes we find increases in the percent pollen abundance of trees and shrubs from moist semi-deciduous forest (Allophylus, Macaranga, Alchornea, Celtis), riparian forest (Phoenix reclinata) and wooded savannah (Acalypha, Rhus-type vulgaris, Combretaceae/Melastomataceae) as well as taxa common in the local rift-valley grasslands (Acacia, Ficus), together creating strong temporary reductions in Poaceae pollen (to $45-55 \%$ of the terrestrial pollen sum). During intervening dry periods, Poaceae pollen attained values of 65-75\%, and dryland herbs such as Commelina, Justiciatype odora and Chenopodiaceae expanded at the expense of Asteraceae, Solanum-type, Swertia usambarensis-type, and (modestly so) Urticaceae. Noting that the overall richness of arboreal taxa remained high but their combined abundance low, we conclude that the landscape surrounding Lake Chibwera has been an open wooded savannah throughout the past 200 years, with historical moisture-balance variation exerting
\end{abstract}

modest effects on local tree cover (mostly the abundance of Acacia and Ficus) and the occurrence of damp soil areas promoting Phoenix reclinata. The strong apparent expansion of true forest trees during wet episodes can be explained partly by enhanced pollen input via a temporarily activated upland stream. Pollen from exotic trees and cultural indicators appears from the 1970s onwards, but their combined influence fails to mask the signature of natural vegetation dynamics in the pollen record.

\section{Introduction}

For East Africa and most other tropical regions where written history extends only to the late-19th century, concrete information on past climate-driven and human-induced landscape dynamics can only be gleaned from natural paleoenvironmental archives preserved in lake and bog deposits. Unfortunately, pollen-based reconstructions of past vegetation change that supposedly indicate (early) anthropogenic deforestation in East Africa are uncertain, partly because traditional paleoecological indicators do not unambiguously separate between natural and anthropogenic impacts on vegetation, and partly because of a long-standing bias against the possibility of significant climate-driven vegetation change within the last few millennia (Verschuren, 2004).

Over the past decade, paleoclimate reconstructions with appropriate time resolution have documented strong lateHolocene moisture-balance variation in both eastern and western portions of the East African Plateau (Verschuren et al., 2000; Verschuren, 2001; Stager et al., 2005; Russell and Johnson, 2005, 2007; Russell et al., 2007; Mills et 
al., 2014). Consequently, socioeconomic and conservation implications of modern-day human impact on East Africa's ecosystems must now be evaluated against the reference background of a continuously changing, inherently unstable physical environment. Parallel reconstruction of climate (Verschuren et al., 2000) and vegetation history (Lamb et al., 2003) in the central Kenyan rift valley over the past 1000 years, extracted from one and the same well-dated sediment record, indicated that at least in semi-arid eastern areas of the East African Plateau, climate-driven moisture-balance fluctuation at decade-to-century timescales may have caused marked shifts in terrestrial vegetation zones. Significant anthropogenic forest clearance there seems to have started only in the 17th century $\mathrm{AD}$, associated with the introduction of maize. Archaeological and linguistic data from regions north and west of Lake Victoria (Reid, 2000; Robertshaw and Taylor, 2000; Killick, 2009; de Filippo et al., 2012) suggest that more humid western areas of the East African Plateau experienced human landscape modification for a substantially longer period of time. Unfortunately, ambiguity in the pollen records of past vegetation history and/or dating mismatches with the separate proxy records of past climate change have so far hampered efforts to distinguish more clearly the climatic and human influences on vegetation history in this region (e.g., Marchant and Taylor, 1998; Taylor et al., 1999; Ssemmanda et al., 2005; Russell et al., 2009; Ryves et al., 2011). As a result, it remains difficult to estimate the magnitude of climatic moisture-balance variation responsible for a certain vegetation change inferred from fossil pollen, and to translate pollen assemblage changes into reconstructions of past vegetation change across the landscape.

In this study, we investigate fossil pollen assemblages in a 200-year high-resolution lake-sediment record from an area of not obviously disturbed savannah in southwestern Uganda to assess the sensitivity of the East African lowland grassland-forest transition to historical, decade-scale trends in climatic moisture balance. Specifically we trace regional vegetation response to three relatively wet episodes known to have occurred in the 1820s-1830s, ca. 1865-1890 and from 1962 to around 2000 . We also analyzed the modern pollen spectra from surface-sediment samples in eight other small lakes bridging the regional grassland-forest gradient, to produce a spatial reference frame for climate-driven vegetation change across the landscape through time.

\section{Study area and environmental setting}

\subsection{Setting of the principal study site}

Lake Chibwera $\left(0^{\circ} 09^{\prime} \mathrm{S}, 30^{\circ} 09^{\prime} \mathrm{E}\right)$ is a medium-sized maar crater lake (76ha) located at $970 \mathrm{~m}$ elevation in the Bunyaruguru lake district of southwestern Uganda, on the floor of the rift valley immediately south of Lake George (Bessems et al., 2008) (Fig. 1). The lake is currently fresh, and had a recorded maximum depth of $11.7 \mathrm{~m}$ in July 2002 and $11.0 \mathrm{~m}$ in August 2008. It is episodically fed by a small creek flowing from nearby Lake Kyamwiga, which in turn receives surface inflow from uplands forming the eastern rift-valley flank (Fig. 1b). Lake Chibwera's own maximum depth is bounded by the sill elevation of a shallow ravine to the north, which during former wetter times may have been an active outlet. Lake Chibwera and its surroundings are situated in the erstwhile Kyambura Game Reserve, which since 1965 forms part of Queen Elizabeth National Park (QENP). The protected rift-valley landscape of QENP occupies an area of ca. $2000 \mathrm{~km}^{2}$ between lakes Edward and George, and encompasses a wide range of vegetation types (from forest to grassland to papyrus swamp) with a full complement of wildlife including large wild mammals (buffalo, lion, elephant). Until the early 1970s, the reserve was used for licensed hunting to support nearby communities. During the period of political instability from the 1970s to early 1990s, uncontrolled hunting throughout the park decimated large-mammal populations, and land in the southern part of the game reserve was occupied by subsistence farmers (Fig. 1). Grazing by domestic livestock, mainly goats, inside the reserve was halted in 1996 when park management was transferred to the Uganda Wildlife Authority (Byaruhanga et al., 2001). Today the largely undisturbed, natural landscape around Lake Chibwera is an open wooded savannah (Fig. 2), composed mainly of the grasses Themeda triandra, Imperata cylindrica and Cymbopogon nardus with dispersed Acacia gerrardii, Acacia sieberiana, Capparis tomentosa and Ficus sp. Bush thickets (evergreen bushland; White, 1983) of Capparis tomentosa and Euphorbia candelabrum shelter shrubs such as Jasmina sp. and Ipomoea sp., and Sporobolus pyramidalis is a common grass. Riparian forests in nearby Kyambura Gorge and along the ravines of ephemeral streams include trees such as Cynometra sp. and Diospyros abyssinica, and the palm Phoenix reclinata in wet open-canopy areas (Krüger and Johnson, 1996; FAO, 2005; Kirabo et al., 2011).

\subsection{Regional climate, vegetation and land use}

The climate of southwestern Uganda is classified as tropical sub-humid, with a bimodal seasonal rainfall regime peaking in March-May and October-December. Rainfall patterns are strongly driven by monsoonal winds from the Indian Ocean, modulated by the north-south passage of the Intertropical Convergence Zone (ITCZ) across the Equator, and associated west-east movement of the Congo Air Boundary (CAB) between Indian Ocean and Atlantic moisture sources (Nicholson, 1996; Mutai and Ward, 2000). Depending on local topography, mean annual rainfall varies between ca. 900 and $1400 \mathrm{~mm} \mathrm{yr}^{-1}$ (Fig. 1b) approaching ca. $1150 \mathrm{~mm} \mathrm{yr}^{-1}$ at the rift-valley margin near Lake Chibwera, and mean annual evaporation varies from ca. 1600 to $1900 \mathrm{~mm} \mathrm{yr}^{-1}$ (Bessems et al., 2008). 


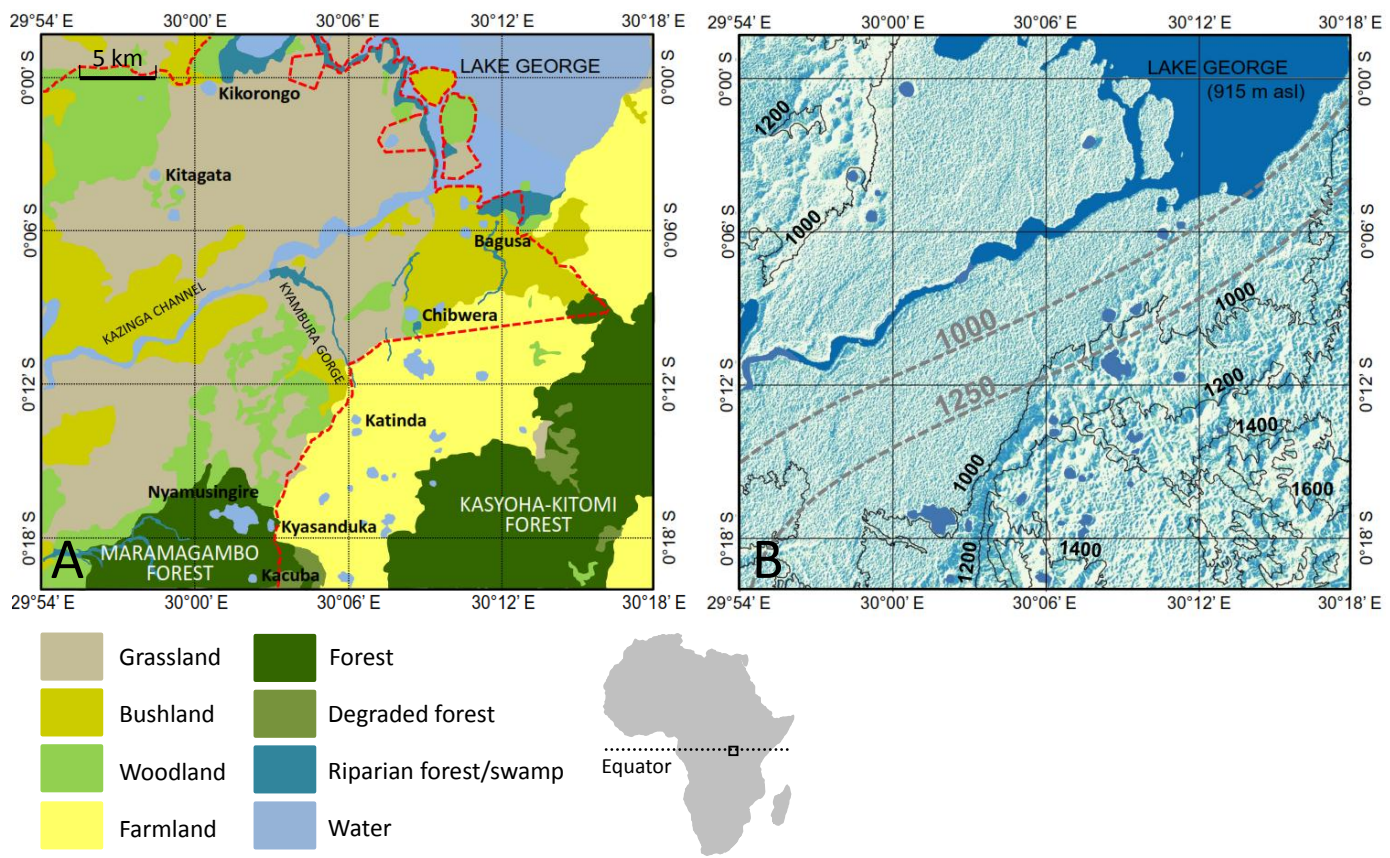

Figure 1. Map of the Bunyaruguru area in southwestern Uganda (equatorial East Africa, cf. inset map) showing the topographical, climatic and vegetation settings of Lake Chibwera and eight other crater lakes within and near Queen Elizabeth National Park serving as pollen reference sites. (a) Modern-day distribution of major vegetation types occupying the rift-valley floor and shoulder south of Lake George, modified from the Uganda Government's National Biomass Study (1996). The red dash-stippled line is the park boundary. (b) Regional topography from the ASTER global digital elevation model (http://earthexplorer.usgs.gov/), with coordinate grid and $200 \mathrm{~m}$ interval elevation contours added using QGIS 2.0.1 Dufour (Quantum GIS Development Team, 1991); superimposed is the distribution of annual rainfall, from the Macmillan Atlas of Uganda (2004).

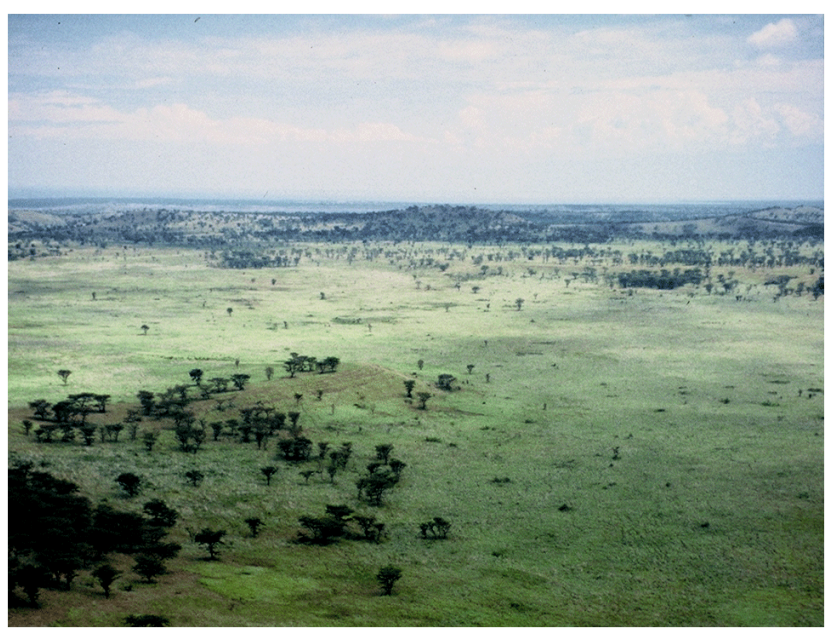

Figure 2. Rift-valley landscape of Queen Elizabeth National Park, showing the mosaic of open grassland and wooded savannah in the vicinity of Lake Chibwera. Photo by Dirk Verschuren.

As indicated by historical gauge measurements and waterlevel reconstructions from Lake Victoria (Piper et al., 1986; Nicholson, 1998; Stager et al., 2005), the region's climatic moisture balance has fluctuated substantially in the past $\sim 200$ years, with episodes of relative drought (e.g., in the late 18th/early century and AD 1920-1962) alternating with episodes of wetter conditions (e.g., $\sim 1865-1885$ and $\sim 1962-2000$; Fig. 3). The level of Lake Victoria is a temporally integrated indicator of rainfall over its catchment (Nicholson et al., 2000); strong coherency of historical lakelevel fluctuations among the East African lakes (Nicholson, 1998; Bergonzini et al., 2004), as well as precipitation field analysis (Nicholson, 2001), suggests that its moisture balance history can be extended to the rift-valley region of western Uganda (Nicholson et al., 2012). Lithostratigraphic analysis of Lake Chibwera sediments (Bessems et al., 2008) had earlier demonstrated the local occurrence of dry/wet climate cycles matching the timing of regional moisturebalance variability as reconstructed from the longer Lake Victoria record nearby (Stager et al., 2005; Fig. 3). Nicholson and Yin (2001) used inverse hydrological modeling to conclude that Lake Victoria's most recent highstand represented a positive rainfall anomaly on the order of $10 \%$ from the long-term mean.

Modern-day vegetation on the uplands $(>1200 \mathrm{~m})$ of the rift-valley escarpment to the southeast of Lake Chibwera is identified as Lake Victoria regional mosaic (White, 1983), which is a forest/savannah mosaic with remnants of evergreen or semi-deciduous forest (specifically the 


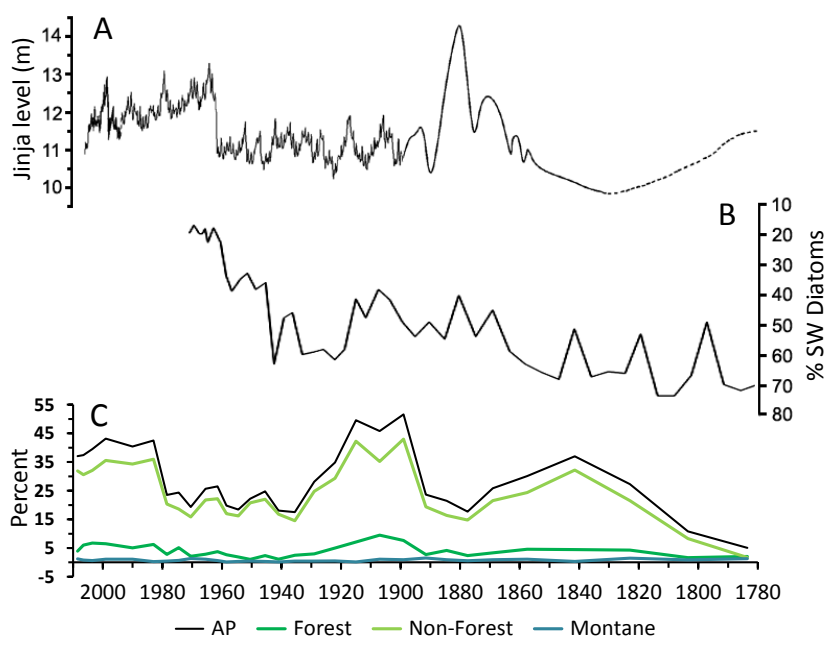

Figure 3. (a-b) Moisture-balance variability in western Uganda during the past $\sim 200$ years, inferred from historical reports and instrumental gauge data of Lake Victoria's water level at Jinja (a, modified after Nicholson and Yin, 2001) and percent shallow-water diatoms (\% SW Diatoms) in dated sediments from a peripheral bay (b, from Stager et al., 2005). (c) Percent total arboreal pollen (AP) in the Lake Chibwera sediment record, as the sum of all montane forest, lowland forest, and woodland/bushland plus rift-valley trees and shrubs (the latter taken together as "non-forest"). The respective curves include significant taxa only, i.e., those shown in Fig. 5.

Kasyoha-Kitomi Forest; Fig. 1), and wooded savanna with trees such as Acacia, Combretum and Euphorbia. Here, persistence of an understory grass layer (mainly Pennisetum purpureum and Themeda triandra) depends on regular burning, either natural or (increasingly) anthropogenic. Demographic pressure has significantly reduced Uganda's natural forests and bushlands (Andrua, 2002). Except for national parks, forest and wildlife reserves, most landscapes in the crater lake districts are now strongly impacted by agricultural activity (cropland and plantations), in our study area to within $2 \mathrm{~km}$ of Lake Chibwera (Fig. 1). The region's remaining fragments of evergreen forest are characterized by Parinari excelsa, Strombosia scheffleri, Drypetes gerrardii and Carapa grandiflora. In semi-deciduous forests at lower elevation (mostly $<1200 \mathrm{~m}$, such as Maramagambo Forest to the south-west of Lake Chibwera; Fig. 1), Maesopsis eminii, Olea welwitschii, Sapium ellipticum and Phyllanthus discoideus characterize the colonizing stage, followed by a succession of mainly Khaya anthotheca, Entandrophragma ssp. and Cynometra alexandri, and climax vegetation composed of Cynometra alexandri with Celtis ssp. and Strychnos mitis (Langdale-Brown et al., 1964; Vincens et al., 1997; Kirabo et al., 2011). Montane rainforest (e.g., Podocarpus milandjianus, Rapanea melanophloeos, Prunus africana) and Afroalpine vegetation (Ericaceae) is restricted to the Rwenzori Mountains (Vincens et al., 1997), over $50 \mathrm{~km}$ to the northwest of Lake Chibwera.

\section{Material and methods}

\subsection{Sediment sampling, lithology and chronology}

Sediment core CHIB02-1P $(0-117 \mathrm{~cm})$ was recovered in two sections from the deepest part of Lake Chibwera, using a rod-operated single-drive piston corer (Wright, 1980). The unconsolidated uppermost sediments $(\sim 25-30 \mathrm{~cm})$ were extruded upright in $1 \mathrm{~cm}$ increments with a fixed-interval sectioning device (Verschuren, 1993), and transferred to Whirl-Pack ${ }^{\mathrm{TM}}$ bags. The deeper, more consolidated sediments were retained intact in the original core tubes (Bessems et al., 2008). Due to depletion of uppermost mud following previous analyses, we extended the Chibwera sequence upward by $9 \mathrm{~cm}$ (now totaling $126 \mathrm{~cm}$ ), using the overlapping UWITEC gravity core CHIB08-1G collected at the same GPS position (Gelorini et al., 2012a). These cores were cross-correlated using data of bulk sediment composition (based on the loss-on-ignition (LOI) method) and magnetic susceptibility, and the depths of lithostratigraphical transitions defined by Bessems et al. (2008) adjusted accordingly. The chronological framework is based on ${ }^{210} \mathrm{~Pb}$ and ${ }^{137} \mathrm{Cs}$ dating, supplemented by two AMS ${ }^{14} \mathrm{C}$ dates on terrestrial plant macrofossils from near the base of the sequence; we refer to Bessems et al. (2008) for details on the analytical procedures. The age-depth model (Fig. 4) is a smoothed spline derived using CLAM software in R (Blaauw, 2010), in which the ${ }^{210} \mathrm{~Pb}$ chronology was anchored to the base of the ${ }^{137} \mathrm{Cs}$ maximum reflecting the nuclear-bomb testing spike of 1963. Given that this maximum is defined by measurements at $4 \mathrm{~cm}$ resolution (representing ca. 4 years, in this section of the core), the true age uncertainty for any particular depth interval in the ${ }^{210} \mathrm{~Pb}$-dated portion of the record is larger than suggested by the $95 \%$ error envelope of the CLAM-derived age model. Our combined ${ }^{210} \mathrm{~Pb} /{ }^{14} \mathrm{C}$-based age model demonstrates continuity of sediment accumulation in Lake Chibwera since its most recent desiccation in the late 18th to early 19 th century.

The composite sequence of Lake Chibwera consists of four lithostratigraphic units (Fig. 5). Unit $1(126-121 \mathrm{~cm})$ is composed of dry but organic clays with few large plant fragments, representing a poorly defined pre-19th century lacustrine phase (Bessems et al., 2008). It is overlain by a horizon of dry clay (Unit 2, 121-112 cm) with modest organic content (11-16\%), marking the lake's complete desiccation (but likely seasonal flooding) during the prolonged episode of extreme regional drought known to have occurred in the late 18th to early 19th century (Verschuren, 2004; Nicholson et al., 2012). This desiccation horizon is overlain by a section of moist, organic peaty clay with abundant coarse plant fragments (Unit 3, 112-101 cm), representing the early to mid-19th century phase of gradual lake filling, characterizing a shallow-water environment with submerged macrophytes and swampy riparian zone. It is followed by soft organic clays (Unit $4,101-0 \mathrm{~cm}$ ), reflecting the true lacustrine 


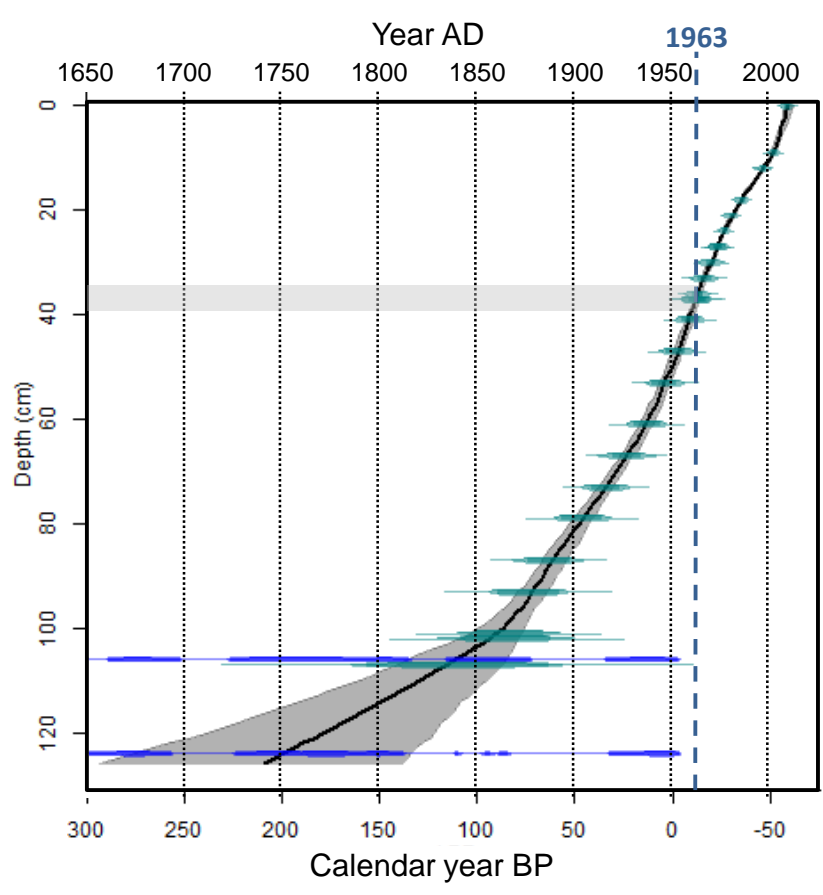

Figure 4. Depth-age relationship of the Lake Chibwera sediment record, based on a smoothed spline through $18{ }^{210} \mathrm{~Pb}$ and $2{ }^{14} \mathrm{C}$ dated intervals (age-probability distributions shown in turquoise and blue, respectively), anchored in the ${ }^{137} \mathrm{Cs}$ maximum of atomicbomb testing in AD 1963 and in the core tops of 2002 and 2008. Uncertainty in the exact depth position of the ${ }^{137} \mathrm{Cs}$ peak $(36 \pm 2 \mathrm{~cm}$, since the measuring interval is $4 \mathrm{~cm}$ : light grey band) allows a range of ${ }^{210} \mathrm{~Pb}$-derived age extrapolations below that level, and thus a greater age uncertainty than suggested by the $95 \%$ error envelope calculated in CLAM (dark grey band; Blaauw, 2010).

phase with mostly higher lake levels which have prevailed from the 1860s until today (Bessems et al., 2008).

The relationship between fossil pollen assemblages and actual vegetation cover across the regional grassland-forest transition was assessed using modern-day pollen spectra in surface-sediment samples from a set of reference lakes (Mathias and Giesecke, 2014), in this case eight other crater lakes situated between the dry floor and wetter shoulder of the rift valley (Fig. 1). Six of these lakes are also located inside the protected area of QENP, and span the vegetation gradient from grass savannah (Kikorongo and Kitagata, both north of Kazinga Channel) to open wooded savannah (Chibwera) or bushland (Bagusa, immediately south of Lake George) to moist semi-deciduous forest (Kacuba, Kyasanduka and Nyamusingire, all in Maramagambo Forest). The two other lakes (Kanyamukali and Katinda) are situated near the original woodland-forest border but now strongly impacted by land clearance and agricultural activity (Fig. 1a). They all have small crater catchments (except Lake Nyamusingire, which occupies a compound crater basin), and range in elevation between 905 and $1150 \mathrm{~m}$. Based on their respective positions in this landscape, local annual rainfall probably ranges from less than $900 \mathrm{~mm}$ (Kitagata) to $1350 \mathrm{~mm}$ (Kacuba) (Fig. 1b and Table 1).

\subsection{Pollen analysis}

From the Chibwera sediment sequence, in total 33 samples of $1 \mathrm{~mL}$ volume were extracted for pollen analysis, mostly from $1 \mathrm{~cm}$ increments at $4 \mathrm{~cm}$ intervals (except for two $3 \mathrm{~cm}$ increments in the uncompacted upper $10 \mathrm{~cm})$. In all other lakes, pollen was extracted from homogenized samples of the upper $3-5 \mathrm{~cm}$ of uncompacted surface muds, which according to ${ }^{210} \mathrm{~Pb}$-dating results (Russell et al., 2007; Bessems et al., 2008) on longer sequences from four of these lakes (Chibwera, Katinda, Kanyamukali, Kitagata) have accumulated in the last ca. 4-10 years. Following standard procedures (Faegri et al., 1989), the samples were treated with warm $10 \% \mathrm{KOH}$, warm $10 \% \mathrm{Na}$ pyrophosphate, $96 \%$ acetic acid, an acetolysis mixture of $1: 9 \mathrm{H}_{2} \mathrm{SO}_{4}$ and acetic anhydride boiled to $100^{\circ} \mathrm{C}$ for $10 \mathrm{~min}$, and finally $96 \%$ ethanol. A bromoform-ethanol mixture with specific gravity 2.0 was used to separate pollen grains from heavier mineral sediment components. The microfossil extracts were then put in glycerine, dried overnight in an oven at $40^{\circ} \mathrm{C}$ and finally mounted on microscope slides.

Pollen (and fern/moss spore) nomenclature and identifications in this study are based on the African Pollen Database (APD) (Vincens et al., 2007; http://medias.obs-mip.fr/apd). In most samples at least 500 terrestrial pollen grains were counted (range 275-1313; mean 638). When Poaceae pollen counts were too low to ensure a solid percent abundance estimate, counting continued until ideally at least 300 Poaceae pollen grains were encountered. Abundances of individual pollen and spore taxa are expressed as percentages of the non-local pollen sum (i.e., excluding (semi-)aquatic taxa such as the Cyperaceae, and ferns and mosses); the results were plotted using TILIA 1.7.16 (Grimm, 2011). Pollen assemblage zones (PAZs) were generated using stratigraphically constrained incremental sum-of-squares cluster analysis (CONISS; Grimm, 1987), applied to the stratigraphic distribution of all terrestrial pollen taxa.

\section{Results}

\subsection{Modern pollen spectra}

Modern pollen spectra of the nine study lakes sorted by vegetation type (Fig. 6) highlight the descending relative abundance of Poaceae pollen across the natural grassland-forest gradient, from $\sim 65 \%$ in grassland with dispersed trees and shrubs (Kitagata and Kikorongo) to $\sim 50 \%$ in open wooded savannah and bushland (Bagusa and Chibwera) and $\sim 35 \%$ in moist semi-deciduous forest (Nyamusingire, Kacuba and Kyasunduka). Poaceae abundance at the impacted lakes Kanyamukali and Katinda is similar to those 
Table 1. Site information on Lake Chibwera and the eight reference lakes analyzed in this study. Geographical coordinates and elevation data are from Garmin ${ }^{\circledR}$ GPS readings; lake depth is the range of maximum echosounder values recorded during successive visits in the period 2001-2008; lake and catchment areas are from topographic maps or Google Earth ${ }^{\circledR}$ images; and rainfall is estimated from each site's position in relation to the rainfall contours in the Macmillan Atlas of Uganda (2004).

\begin{tabular}{lccccccc}
\hline Lake name & Latitude & Longitude & $\begin{array}{c}\text { Elevation } \\
(\mathrm{m})\end{array}$ & $\begin{array}{c}\text { Depth } \\
(\mathrm{m})\end{array}$ & $\begin{array}{c}\text { Area } \\
(\text { ha })\end{array}$ & $\begin{array}{c}\text { Catchment } \\
(\text { ha })\end{array}$ & $\begin{array}{c}\text { Rainfall } \\
(\mathrm{mm})\end{array}$ \\
\hline Kitagata & $0^{\circ} 04^{\prime} \mathrm{S}$ & $29^{\circ} 58^{\prime} \mathrm{E}$ & 915 & $7.5-8.0$ & 62 & 180 & 900 \\
Kikorongo & $0^{\circ} 00^{\prime} \mathrm{S}$ & $30^{\circ} 01^{\prime} \mathrm{E}$ & 915 & $9.8-10.7$ & 92 & 128 & 900 \\
Bagusa & $0^{\circ} 06^{\prime} \mathrm{S}$ & $30^{\circ} 11^{\prime} \mathrm{E}$ & 905 & $0.5-0.9$ & 33 & 104 & 1000 \\
Chibwera & $0^{\circ} 09^{\prime} \mathrm{S}$ & $30^{\circ} 09^{\prime} \mathrm{E}$ & 970 & $11.0-11.7$ & 76 & 98 & 1150 \\
Kanyamukali & $0^{\circ} 24^{\prime} \mathrm{N}$ & $30^{\circ} 14^{\prime} \mathrm{E}$ & 1150 & $10.4-11.4$ & 2 & 5 & 1250 \\
Katinda & $0^{\circ} 13^{\prime} \mathrm{S}$ & $30^{\circ} 06^{\prime} \mathrm{E}$ & 1030 & $16.0-16.3$ & 45 & 79 & 1250 \\
Nyamusingire & $0^{\circ} 17^{\prime} \mathrm{S}$ & $30^{\circ} 02^{\prime} \mathrm{E}$ & 975 & $4.3-4.5$ & 384 & 487 & 1300 \\
Kacuba & $0^{\circ} 20^{\prime} \mathrm{S}$ & $30^{\circ} 01^{\prime} \mathrm{E}$ & 1100 & 14.5 & 51 & 73 & 1350 \\
Kyasanduka & $0^{\circ} 17^{\prime} \mathrm{S}$ & $30^{\circ} 25^{\prime} \mathrm{E}$ & 1005 & $2.0-2.5$ & 50 & 89 & 1300 \\
\hline
\end{tabular}

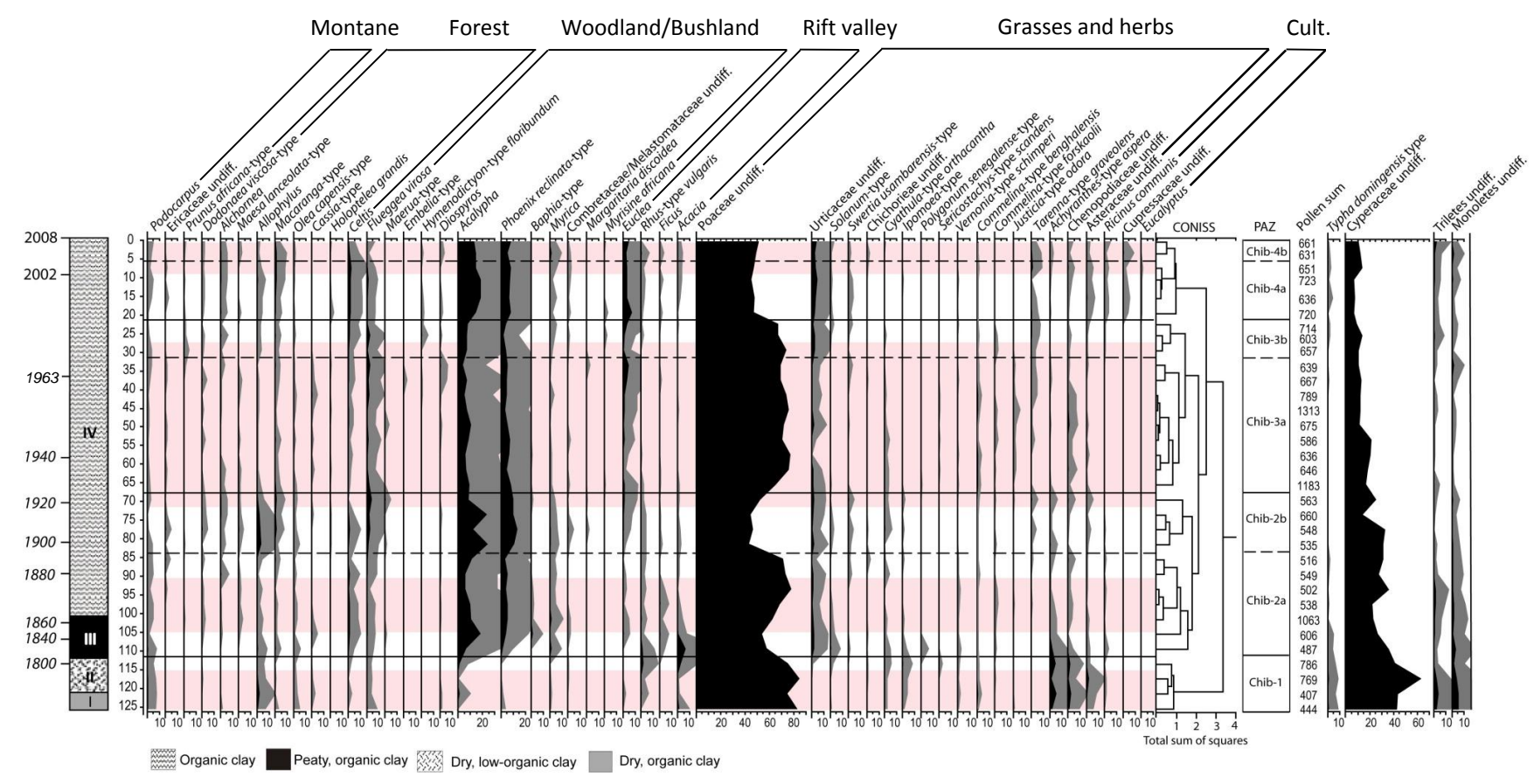

Figure 5. Stratigraphic distribution and zonation of selected pollen taxa (all taxa with minimum overall abundance of $0.5 \%$ ) in the Lake Chibwera sediment sequence, in relation to lithostratigraphy (Units I-IV). lithostratigraphy (Units 1-4) and sediment age (Bessems et al., 2008; Fig. 4). Taxon abundances are expressed as percentages of the terrestrial pollen sum (black, with $\times 5$ exaggeration curves in grey). To the extent possible, taxa are ordered left to right from indicating more moist (upland, closed) vegetation to more dry (lowland, open) vegetation within the study area. The "rift valley" category groups arboreal taxa occurring as dispersed trees in open grassland. Inferred dry phases (increasing Poaceae values) are highlighted by pink shading. PAZ: pollen assemblage zone.

of open wooded savannah, despite their position close to the original woodland-forest boundary. Removal of trees and shrubs for agricultural purposes in the vicinity of these lakes created pollen assemblages that are seemingly derived from vegetation growing under drier climatic conditions (cf. Vincens et al., 2003). Assemblages from the anthropogenically impacted sites Katinda and Kanyamukali are readily distinguished by high percentages of Asteraceae (5.4 and
$14.5 \%$, respectively) and the cultural indicator Ricinus communis (3.6 and 7.0\%). Pollen from the exotic Eucalyptus, introduced in Uganda from the mid-20th century onwards (Langdale-Brown et al., 1964), is common (8\% of the pollen sum) in Lake Kanyamukali, but in Lake Katinda (ca. $2 \%$ ) it is not more common than at the three semi-deciduous forest sites and Lake Bagusa, which are all located inside QENP but within a few kilometers of densely populated areas. These 


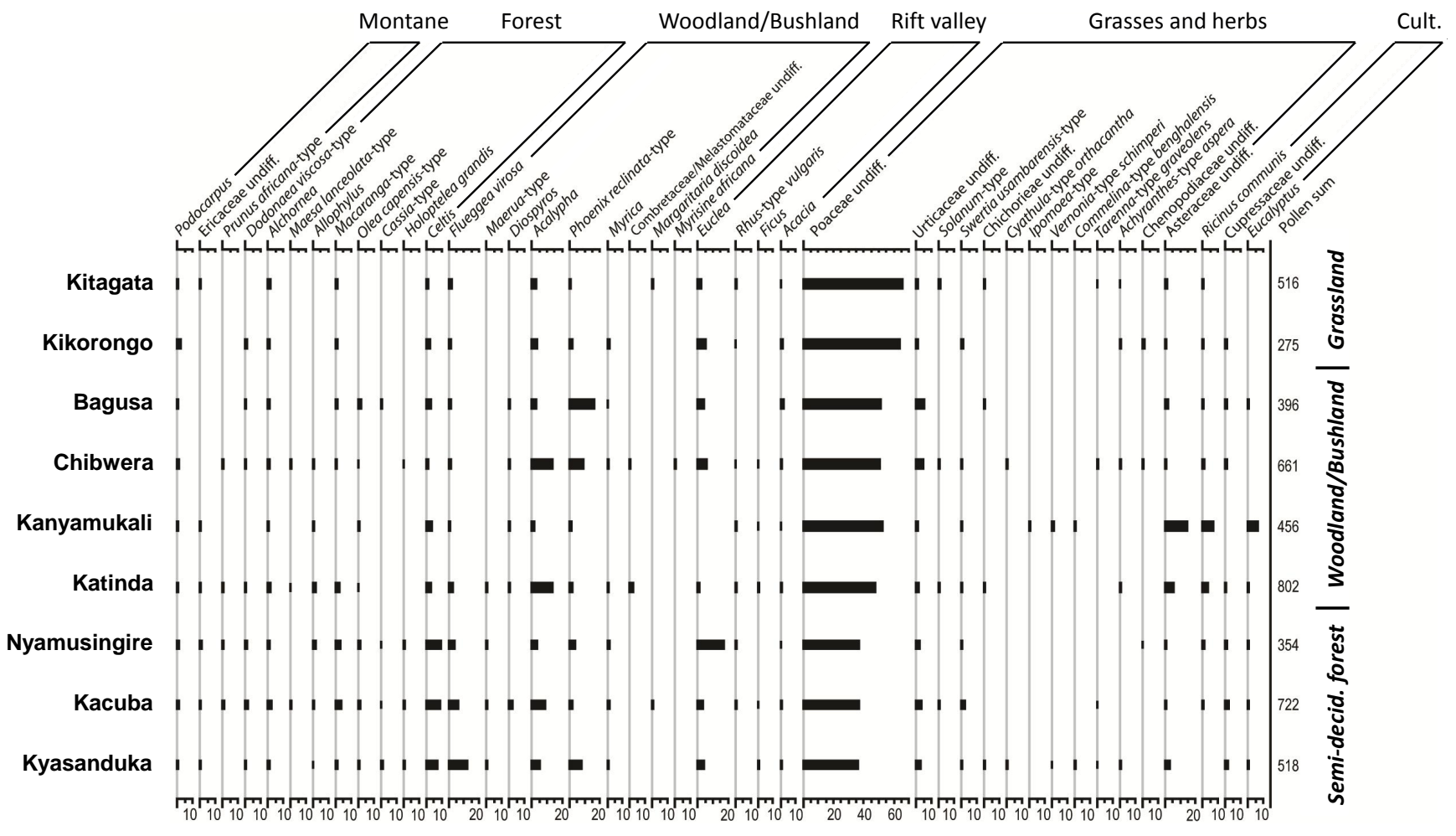

Figure 6. Percent abundances of selected terrestrial pollen taxa in the surface sediments of Lake Chibwera and eight reference lakes in the Bunyaruguru area. The selection is identical to that of Fig. 5, minus seven taxa (Baphia-type, Embelia-type, Hymenodictyon-type floribundum, Sericostachys-type scandens, Polygonum senegalense-type, Commelina-type forskalaei and Justicia-type odora) not found in these surface-sediment samples. Sites are ordered from top to bottom according to their position along the regional grassland-forest gradient. Cyperaceae and other local (semi-)aquatic taxa are not shown because their abundance is strongly site-specific and not included in the pollen sum.

values are consistent with a land-use survey in 25 Ugandan crater basins (Gelorini et al., 2012b), which recorded Eucalyptus plantation covering $\sim 15 \%$ of the Kanyamukali crater catchment but lacking at Lake Katinda. Considering the limited dispersal potential of Eucalyptus pollen (FAO, 2005), its abundance in our surface-sediment samples is likely inversely proportional to distance from its nearest important pollen source in farmlands to the east, southeast or north of the study area.

The case of Eucalyptus highlights the "mixed" pollen assemblages which result from a mosaic distribution of natural and impacted vegetation types within individual sites' relevant pollen source area (cf. Vincens et al., 2006). This also explains the presence of typical savannah trees (Acacia, Maerua, Euclea) in our pollen spectra from inside Maramagambo Forest; although park vegetation immediately surrounding all three lakes is not obviously disturbed, farmland or degraded forest occurs to within a few kilometers of these sites (Fig. 1a). The percent Poaceae pollen recorded at our three forest sites nevertheless remains markedly lower than at our open wooded savannah sites (Fig. 6). Similarly, the presence of Acalypha (here most likely the low-stature woodland shrubs A. fruticosa and A. indica), Phoenix reclinata-type and Celtis in pollen spectra from grassland sites can be considered "contamination" from more densely wooded savannah and/or strips of riverine forest nearby, or from more distant semi-deciduous forest. Nevertheless, the percent grass pollen recorded at the true grassland sites remains markedly higher than at wooded savannah sites (Fig. 6).

The apparent over-representation of Poaceae at our three forest sites is consistent with the results of Duffin and Bunting (2008), who in the mosaic vegetation of a southern African savanna found that local grasses produced about twice as much pollen as the arboreal taxa. Nevertheless, in our study region the summed pollen percentage of true forest trees increases from 5.1-13.8\% in grass and woodland savannah sites to $12.5-20.9 \%$ at the three sites inside semideciduous Maramagambo Forest. Pollen from Podocarpus and Prunus africana-type originates from Afromontane vegetation on the Rwenzori Mountains, at least $30 \mathrm{~km}$ away. Also the modest amount of Ericaceae pollen recovered at our reference lakes likely originates in the Rwenzori, although the occurrence of short-stature Ericaceae on the local rift-valley escarpment cannot be excluded (H. Osmaston, personal communication, 2005). Pollen from Olea capensistype (likely Olea welwitschii) and Allophylus is associated 
with evergreen and moist semi-deciduous forest (Vincens et al., 2006), and here most likely originates from the Kasyoha-Kitomi Forest Reserve, situated at slightly higher elevations along the eastern rift-valley escarpment to the southeast of our study area. This is also the likely source of Dodonaea viscosa-type and Alchornea pollen, given their rather indifferent values across our nine study sites. The decreasing trend in percent Poaceae from grass savannah to wooded savannah and semi-deciduous forest is mostly compensated by local or regional trees and shrubs (Fig. 6). Wooded savannah sites (except the impacted Kanyamukali) show elevated percentages of Acalypha and/or Phoenix reclinatatype, whereas Maramagambo Forest sites show elevated percentages of Celtis and Flueggea virosa, besides less pronounced increases in Acalypha and Phoenix. Acacia and Rhus-type vulgaris show an opposing trend, with slightly greater percentages in some grass and wooded savannah sites than in Maramagambo Forest sites. The common woodland tree Euclea displays highly variable occurrences. Among herbaceous taxa, percentages of Urticaceae are markedly higher in the two wooded vegetation types than in open grassland, consistent with its preference for shaded places at forest edges, in wooded savannah, or along streams (Friis, 1989).

In summary, pollen assemblages from the region's modern-day open grassland can be distinguished by $\sim 65 \%$ Poaceae accompanied by Acacia and Rhus-type vulgaris, characteristic of plant functional type $\operatorname{tr} 3+\mathrm{g}$ in the East African SAVA (savannah) biome (Vincens et al., 2006). Other typical SAVA trees, however, are here associated with degraded portions of the semi-deciduous forest (Maerua of the Capparidaceae and Flueggea virosa) or display an erratic distribution across sites (Euclea). Pollen assemblages of wooded savannah are distinguished by $\sim 50 \%$ Poaceae with strong contributions of Acalypha and/or Phoenix reclinatatype, and further Olea and Combretaceae/Melastomataceae. Pollen assemblages from semi-deciduous forest are distinguished by $\sim 35 \%$ Poaceae and diverse arboreal taxa of plant functional type tr1 in the East African TSFO (tropical seasonal forest) biome (Vincens et al., 2006), such as Celtis, Holoptelea grandis, Cassia-type, Macaranga-type, Olea and Allophylus.

\subsection{Pollen stratigraphy of the Chibwera sediment sequence}

CONISS stratigraphic zonation of fossil pollen assemblages in the Chibwera sediment sequence defines four major pollen assemblage zones (Chib-1 to Chib-4), of which the latter three are each subdivided in two distinct subzones (Fig. 5).

Zone Chib-1 (126-111 cm, 18th century) is stratigraphically related to the dry, mostly low-organic clays which were deposited when Lake Chibwera stood low or (at least seasonally) dry (Units 1-2); consequently, the four assemblages comprising this basal zone may not necessarily represent an uninterrupted sequence. They are characterized by very high Poaceae abundances (75-85\%) and the common presence of Asteraceae, Chenopodiaceae and Amaranthaceae (Achyranthes-type aspera), with minor contributions of Ipomoea-type and Vernonia-type schimperi. Pollen from Podocarpus, Allophylus and Olea represents long-distance dispersal from either the Rwenzori or the eastern rift-valley escarpment. Pollen from other trees and shrubs is scarce, with only small and often occasional occurrences of Acacia, Rhus-type vulgaris and Flueggea virosa. The overall terrestrial pollen assemblage suggests that vegetation surrounding Lake Chibwera was a dry grassland with less tree cover than modern-day savannah at any of our reference sites. The abundant Cyperaceae pollen (40-60\%) in this zone, supplemented with Typha domingensis-type, suggests that much of the seasonally flooded dry lake floor was occupied by a sedge swamp with cattails, and mosses and ferns (monolete and trilete spores; Fig. 5) growing at their base. Together, the pollen evidence implies a climatic moisture balance markedly more negative than today, consistent with the lithostratigraphy (Bessems et al., 2008).

Subzone Chib-2a (111-84cm, ca. 1820-1895) corresponds with the section of organic peaty clay (Unit 3 ) deposited under the shallow and swampy, but permanent lacustrine conditions during the first half of the 19th century, and the lower part of organic lake muds deposited under shallow to deep lacustrine conditions from about 1860 onwards (Unit 4). In the temporal sequence of pollen assemblages, three successive phases can be discerned. At the base of this subzone marked decreases of Poaceae (to 55-60\%), Asteraceae, Chenopodiaceae and Achyranthes-type aspera are compensated by a temporary expansion of Acacia and Rhustype vulgaris, along with the herbs Polygonum senegalensetype and Solanum-type. Myrica and the Urticaceae record similarly rapid but more long-term increases. Shortly thereafter the summed abundance and richness of woodland and semi-deciduous forest tree taxa increases strongly, most notably by Acalypha and Phoenix reclinata-type but also Ficus, Myrica, Celtis, Flueggea virosa, Euclea, Baphia-type and Combretaceae/Melastomataceae. Together with the common presence of Urticaceae, this diversification of tree taxa and reduction in Poaceae suggests wetter climatic conditions promoting the development of a type of wooded savannah not unlike the vegetation surrounding Lake Chibwera today (compare with Fig. 6). The strong reductions in Cyperaceae (to $25 \%$ ), Typha domingensis-type and undifferentiated fern and moss spores reflect lake filling, in which emergent aquatic vegetation retreated to a more or less narrow belt along the shoreline. However, in the upper half of this subzone (dated to between 1850 and 1895), Poaceae pollen abundance increases again to $70-80 \%$, along with a renewed increase of Chenopodiaceae, and appearances of other dryland herbs such as Commelina-type forskalaei, Tarenna-type graveolens and Justicia-type odora. Expansion of these taxa is mostly at the cost of Acalypha, but also of Ficus, Myrica, Euclea and Baphia-type along with Solanum-type herbs. 
The simultaneous increase in Cyperaceae pollen (peaking at $35 \%$ ) suggests an expansion of the littoral sedge swamp and thus a lowering of lake level, but this is not clearly recorded in the lithostratigraphy.

Pollen assemblages of subzone Chib-2b $(84-67 \mathrm{~cm}$, ca. 1895-1925) are characterized by a strong decline in Poaceae pollen to its lowest level $(45 \%)$ of the entire sequence, accompanied by strong rises in woodland and semi-deciduous forest trees such as Acalypha, Phoenix reclinata-type, Celtis, Flueggea virosa and Euclea, but also moist forest trees such as Allophylus, Macaranga-type and Dodonaea viscosa-type. Also Alchornea, mostly rare before, is now consistently present. Among the herbaceous taxa, the Urticaceae do well but also Asteraceae, Cyathula-type orthocantha, Solanumtype, Swertia usambarensis-type and Tarenna-type graveolens; in contrast, Chenopodiaceae disappear almost completely. Within the group of aquatic taxa, Cyperaceae retreats from its earlier maximum, although not in synchrony with the reduction in Poaceae. Overall this pollen subzone suggests the presence of wooded savannah with greater tree cover than today, and more damp soil habitat promoting Phoenix reclinata. The increases in Allophylus, Macaranga-type, and Celtis trees suggest a simultaneous expansion of nearby evergreen and semi-deciduous forest, all indicative of climatic conditions significantly wetter than today.

Subzone Chib-3a (67-31 cm, ca. 1925-1970) is characterized by the strong rebound of Poaceae pollen to 70-75\%, whereas woodland trees such as Myrica, Flueggea virosa, Acalypha and Phoenix reclinata-type, as well as Celtis and all forest trees, experience modest to strong reductions. Among the herbaceous taxa, Asteraceae and Cyathula-type orthacantha of the Amaranthaceae almost disappear, and also Urticaceae are less common than throughout zone Chib2. The Chenopodiaceae again expand in synchrony with the Poaceae, supplemented by Commelina types benghalensis and forskalaei, and Justicia-type odora (the latter for the first time consistently present). The Cyperaceae initially maintain their starting value of ca. $20 \%$, but then somewhat unexpectedly fall to values of ca. $10 \%$ in the upper half of this subzone. Overall, this pollen subzone documents the return of a more negative climatic moisture balance, and the resulting decline of tree cover in the wooded savannah surrounding Lake Chibwera.

The three pollen assemblages defining subzone Chib$3 b$ (31-21 cm, ca. 1970 to the late 1980s) are broadly similar to those of Chib-3a, except for increases in $\mathrm{Al}$ lophylus, Myrica, Celtis, the Urticaceae and Tarenna-type graveolens, re-appearance of Alchornea, and the (neardisappearance of Chenopodiaceae, Commelina-type benghalensis and Justicia-type odora. These species responses suggest the return of a wetter climate; however the percent abundances of Acalypha and Phoenix reclinata-type remain modest, and Poaceae values remain high at $65-75 \%$, i.e., similar to values in the grassland with limited tree cover near lakes Kitagata and Kikorongo today.
Pollen zone Chib-4 (21-0 cm, late 1980s-2008) is characterized by the appearance of exotic cypress and eucalyptus trees (Cupressaceae and Eucalyptus in Fig. 5), along with now solid presence of the cultural indicator Ricinus communis (which had its first appearance in subzone Chib$3 b)$. Also the return of Asteraceae is now likely promoted by the intensified land use for subsistence farming outside (and encroaching into) QENP. Subzone Chib-4a $(21-6 \mathrm{~cm}$, late 1980s to ca. 2004) groups four samples with greatly reduced Poaceae values (45-50\%), modest to large increases in Celtis, Acalypha and Phoenix reclinata-type, and relatively strong presence of Macaranga-type, Myrica, Euclea, Alchornea, and Combretaceae/Melastomataceae. Also notable is the re-appearance of Acacia, Rhus-type vulgaris and Ficus, with modest values but nevertheless a more prominent occurrence than at any time since the early 19th century. Among the herbaceous taxa we note the high abundances of Urticaceae, and continuous presence of Swertia usambarensis. Among the aquatic taxa, the very low values of Cyperaceae pollen $(10 \%)$ indicate that a highstand of Lake Chibwera flooded most of the fringing sedge swamp which previously must have existed inside its crater basin. Typha domingensis-type seems to have thrived better than before, unless its pollen was brought to Chibwera from cattail stands along the inflowing stream. This pollen subzone documents the now full-scale response of regional vegetation to a more positive climatic moisture balance, initiated in subzone Chib3b. Given limited influence of all exotic plant taxa (not locally, but within the pollen source area) on the percent abundance of Poaceae pollen (together 4-5\%), this pollen zone documents the third episode of expanding tree cover in the savannah surrounding Lake Chibwera in the past 200 years.

Subzone Chib-4b (6-0 cm, ca. 2004-2008), finally, groups the two most recent pollen assemblages, which are characterized by a modest increase in Poaceae (to $50 \%$ ) and reductions in, amongst others, Celtis, Acalypha, Macaranga, Allophylus, Combretaceae/Melastomataceae, and Swertia usambarensis. Woodland taxa such as Phoenix, Euclea and Alchornea remain stable, creating uncertainty as to whether increasing Poaceae pollen actually reflects vegetation response to a new trend of climatic drying. The recent reductions in Allophylus and Celtis pollen may also result from human encroachment into the Kasyoha-Kitomi forest. The only robust indication in the Chibwera pollen record of a recent drying trend is the doubling of Cyperaceae pollen in subzone Chib4b compared to Chib-4a, which we interpret to reflect expansion of the local sedge swamp, and thus a lowered lake level. 


\section{Discussion}

\subsection{Pollen-assemblage signatures of vegetation response to climate change}

Alternating opposite trends in the percent abundances of grass (Poaceae) pollen and some arboreal taxa, particularly Acalypha and Phoenix reclinata-type, in the Lake Chibwera record define a historical sequence of six distinct episodes of climate-driven vegetation change in the past $\sim 250$ years. To a large extent, stratigraphic zone boundaries determined by numerical clustering of successive pollen assemblages (Fig. 5: CONISS zones Chib-1 to Chib-4b) coincide with the levels where shifts (increases/decreases) in the Poaceae percentage curve become apparent.

Three episodes of inferred dry climatic conditions (late 18th century to ca. 1810 , ca. $1840-1880$, ca. 1920-1980; red shading in Fig. 5) are characterized by high (>70\%) or rising percentages of Poaceae pollen, and solid presence of herbaceous taxa such as the Chenopodiaceae, Justicia-type odora, and Commelina types benghalensis and forskalaei. Chenopodiaceae pollen is commonly used as indicator of vegetation disturbance by humans (e.g., Taylor et al., 2005; Drescher-Schneider et al., 2007). However, chenopods also occur naturally in African grasslands visited by large wild herbivores (Gelorini and Verschuren, 2012). Peak Chenopodiaceae abundances (up to $3 \%$ ) in pollen zone Chib-1 indicate that these plants expanded on and around the seasonally flooded Chibwera lake bed during the late 18th-century drought, possibly benefiting from soil disturbance caused by large mammals.

The three inferred wet phases (ca. 1810-1840, ca. 1880-1920, ca. 1980-2000; Fig. 3) are characterized by low $(45-50 \%)$ or decreasing percentages of Poaceae pollen, and at least modest increases in local savannah trees and shrubs (Acacia, Rhus-type vulgaris) and herbs such as Asteraceae, Urticaceae, Solanum and Swertia usambarensis-type. Also taxa of denser woodland and shrubland (Acalypha, Myrica, Combretum), riparian forest (Phoenix reclinata-type) and moist or semi-deciduous forest (Celtis, Macaranga-type, Alchornea, Allophylus) show a repeated positive response during these episodes. Clear peaks in (otherwise rare) Ericaceae pollen during the latter two of these periods support our earlier suggestion that this pollen may originate from lowelevation heather species occurring along the nearby riftvalley escarpment, rather than from the Afroalpine zone in the distant Rwenzori. The strongest responses (i.e., with greatest impact on the relative abundance of Poaceae) occur in Acalypha and Phoenix reclinata-type. Some savanna trees, such as Euclea and Flueggea virosa, resemble the latter two taxa by expanding strongly at the end of the lake drystand ca. AD 1810, but then show fairly stable (Flueggea) or gradually increasing (Euclea) abundances over the following 200 years. Trends in Asteraceae are mostly opposite to those in Poaceae, except that both peak during the late 18th-century drought. Even allowing for some promotion of Asteraceae by intensified human activity along park boundaries since the 1980s (Fig. 5: zone Chib-4a), it appears that, in this open wooded savannah, Asteraceae tend to benefit from increased moisture while also having taken advantage of new habitat created by a lake drystand.

The inferred alternation of wet and dry episodes in the Chibwera region over the past $\sim 250$ years is consistent with historical data and independent lake-based reconstructions of East African climate change within recent centuries (Verschuren, 2004). Severe late-18th century drought (lasting until AD 1815-1820) followed by higher rainfall in the 1820s (Nicholson et al., 2012) has now been documented as a cycle of desiccation and refilling in shallow lake basins throughout equatorial East Africa (e.g., Verschuren, 1999; Russell et al., 2007; Bessems et al., 2008; De Cort et al., 2013). Compilation of historical records indicates that the region's climate was again relatively dry from the 1830 s to the early 1850 s (Nicholson, 2001; Nicholson et al., 2012). Lake Victoria is said to have risen rather steadily in the first decades after its discovery in $\mathrm{AD} 1858$, until reaching its highest documented level in AD 1878. This was followed by a rapid decline in the late $1880 \mathrm{~s}$, and relative stabilization around its presentday level from the 1890s until 1961-1962, when exceptional rainfall caused high Nile discharge and lake transgressions across East Africa (Flohn, 1987). Notwithstanding intermittent dry years in the 1970s and 1980s, this somewhat more positive regional moisture balance has been maintained for four decades; only within the last decade has Lake Victoria regressed to levels approaching its pre-1961 mean (Fig. 3). Also the level of Lake Chibwera fell $0.7 \mathrm{~m}$ between our field campaigns in July 2001 and August 2008; the accompanying expansion of riparian wetland likely explains the more substantial presence of Cyperaceae pollen in the uppermost sediments (zone Chib-4b). The lake-level reconstruction for Lake Victoria by Stager et al. (2005), which is based on the percent abundance of shallow-water diatoms in the sediment record of one of its peripheral bays, confirms that, in the late 18th and earliest 19th centuries, also Lake Victoria stood lower than at any time since then (Fig. 3).

Congruence of the temporal pattern of pollen-inferred vegetation change around Lake Chibwera with this history of regional moisture-balance change strongly suggests a causal relationship. However, the exact timing of the reconstructed vegetation changes appears delayed relative to the improving or deteriorating moisture balance which is likely to have caused them (Fig. 3). The Chibwera record's conformable and high-resolution ${ }^{210} \mathrm{~Pb}$ chronology notwithstanding (Fig. 4; Bessems et al., 2008), we attribute part of this age discrepancy to dating uncertainty, which increases down-core from a few years in late 20th-century sediments to several decades in the 19th-century portion of the record. Still, the late 20th-century vegetation response which was likely caused by increased moisture starting in the early 1960s is recorded in sediments dated to the 1970s up to 
ca. 1980 (the Chib-3b/Chib-4a zone boundary), i.e., well above the ${ }^{137} \mathrm{Cs}$ marker horizon of peak nuclear-bomb testing in 1963 (at $36 \pm 2 \mathrm{~cm}$; Figs. 4 and 5). Taxa such as $\mathrm{Al}$ lophylus, Myrica, Rhus-type vulgaris, Celtis, Alchornea and Urticaceae expanded rapidly (already at the base of zone Chib-3b), followed by Solanum-type and Swertia-type, and finally by Acalypha and Phoenix reclinata-type; it is the latter which drive much of the recorded decline in Poaceae pollen. This modest but real lag in the region's vegetation response to improved moisture balance suggests that it involved real changes in plant community composition, due to higher recruitment and survival of mesophilic (moisture-loving) taxa. If the observed pollen signal merely reflected a phase of temporarily enhanced pollen production of the existing community of such taxa, a more immediate response could have been expected.

\subsection{Sources of pollen deposited in Lake Chibwera sediments}

Lake Chibwera occupies a low-rimmed maar crater basin, situated in an open grass-dominated landscape grading into wooded savannah and then forest occupying the rift-valley shoulder to the north and south (Fig. 1). As a result, both today and in the past Lake Chibwera has captured pollen from a variety of vegetation types: distant Afromontane forest, closed-canopy lowland evergreen and semi-deciduous forests, open-canopy wooded and shrub savannah, and treeless grassland. The pollen record of vegetation change recorded in its sediments therefore reflects vegetation response to climate change both in the immediately surrounding landscape (excluding the truly local (semi-)aquatic vegetation) and at a broader regional scale (cf. Jackson, 1990; Sugita, 2013). Discerning between them is facilitated by a detailed comparison with the composition of pollen spectra deposited today at the reference sites (Mathias and Giesecke, 2014). In this study, these are distributed across the regional grassland-forest transition which in turn reflects a (largely topographic) gradient in climatic moisture balance. Also the relevant pollen source areas of each reference site, which for "medium-sized" lakes in these (semi-)open forests, woodlands and grasslands are on the order of $600-900 \mathrm{~m}$ in diameter (Duffin and Bunting, 2008; Sugita, 2013), encompass multiple types of vegetation, resulting in mixed assemblages (cf. Sect. 4.1). Nevertheless, systematic differences in the percent abundance of characteristic taxa associated with each vegetation zone help to assess the magnitude of vegetation change which occurred at Lake Chibwera in the last $\sim 250$ years.

The largest fraction of pollen preserved in the sediments of small- and medium-sized lakes originates from vegetation in their near surroundings (Jacobson and Bradshaw, 1981; Broström et al., 2004; Duffin and Bunting, 2008), and is delivered to the lakes either by wind, precipitation or local surface run-off (Moore et al., 1991). This includes the typically airborne pollen of Poaceae, Euclea, Capparidaceae species, Flueggea virosa, Rhus-type vulgaris and other common savannah taxa, and of some trees in the forest of Kyambura gorge ca. $6 \mathrm{~km}$ to the west. Pollen of Afromontane Podocarpus and Prunus africana-type must be advected exclusively by wind, from the Rwenzori Mountains. An unknown but sizable fraction of pollen from Celtis, Macaranga, Allophylus and Dodonaea viscosa-type, which grow in either undisturbed or degraded fragments of moist and semi-deciduous forest on the eastern rift-valley flank, reaches Lake Chibwera by surface inflow via Lake Kyamwiga and a swampy depression between them. This may also be the case for $\mathrm{Cu}$ pressaceae and Eucalyptus, plantations of which now partly replace this forest. In the case of Cupressaceae, however, an alternative pollen source is cypress trees planted in the 1980s at a camping site in the direct vicinity of Lake Chibwera (Gelorini et al., 2012a). Advection by wind from intact forest further to the east (Kasyoha-Kitomi) or south (Maramagambo) likely contributes a lesser fraction of the forest-tree pollen reaching Lake Chibwera, considering that the distance to these sources exceeds $10 \mathrm{~km}$.

The principal source of Phoenix reclinata-type and Acalypha pollen, the two taxa showing the strongest response to climate-driven moisture-balance change in the Chibwera record, is uncertain. Phoenix reclinata is a characteristic component of local stands of riparian forest; hence stream inflow from distant stands is potentially a major contributor. However, riparian forest also occurs in shallow ravines traversing the savannah to the north and west of Lake Chibwera (Fig. 1), and it occupies sizable areas of damp soil in a dry crater basin immediately to its south. Thus, increasing abundance of Phoenix reclinata-type pollen may reflect a true expansion of riparian forest and damp soil habitat in the near vicinity of Lake Chibwera, with deposition of winddispersed pollen. Similarly, stream inflow is a likely source of pollen from Acalypha shrubs growing along distant forest margins, but Acalypha fruticosa is a shrub of dry bushlands and shrub savanna (Hemp, 2006), such as now occurs immediately to the north of Lake Chibwera towards Lake George (Fig. 1). Crucially, for both Acalypha and Phoenix, the fraction of pollen contributed by stream inflow may vary together with climatic moisture balance, such that the effective size of Lake Chibwera's pollen source area for these taxa cannot be assumed constant through time. A wetter climate is likely to both promote populations near Lake Chibwera and enhance the input of pollen from more distant (potentially stable) stands.

\subsection{Vegetation history of open woodland savannah in the rift valley of western Uganda}

Throughout the $\sim 250$-year time window represented by the studied sediment sequence, Lake Chibwera has been situated in an open wooded savannah - or according to the classification of Vincens et al. (2006), vegetation of plant 
functional type $\operatorname{tr} 3+\mathrm{g}$ belonging to the SAVA biome. This is indicated by the continuously high (variable, but always $>45 \%$ ) percentages of Poaceae pollen, the low combined percentage of trees and shrubs with a Sudanian (White, 1983) phytogeographical affinity such as Euclea, Maerua and Acacia, and the consistent presence of dryland herbs belonging to Amaranthaceae, Chenopodiaceae and Commelinaceae. Dry phases in the Chibwera pollen record display higher Poaceae percentages (maxima of 75-80\%) than recorded in the modern-day samples from our two grassland sites, in which they account for ca. $63-67 \%$ of the pollen sum. This implies that, during historically dry episodes within the past $\sim 200$ years, treeless grassland was more extensive in the landscape around Lake Chibwera than is the case today at QENP sites located within the dry rift valley between lakes Edward and George (Fig. 1). Even fewer woodland trees and shrubs were present during the late-18th century drought when Lake Chibwera stood dry, but Poaceae pollen did not attain higher percentages because of peak contributions from herbs (Asteraceae, Achyranthes, chenopods) growing on and around the dry lake bed.

In the pollen assemblage of the earliest wet episode, dated to the mid-19th century, Poaceae drops to percentages of ca. $55 \%$, equivalent to those of Lake Chibwera and other open wooded savannah sites within QENP today. The two other recognized wet episodes, dated to the late 19th to early 20 th century and the last decades of the 20th century, display grass pollen values that are substantially lower still (45-50\%), approaching that of our reference sites located in protected semi-deciduous forest. It is doubtful that during these wet periods the entire landscape around Chibwera developed high tree cover. Certainly, wetter climatic conditions must have promoted recruitment and survival of the dispersed Acacia and Ficus trees which today occur throughout much of the open rift-valley grassland (Fig. 2). However, excluding Acalypha and Phoenix reclinata-type, the combined abundance of forest tree taxa always remained rather low, and many taxa are found only occasionally. Together, this implies an always distant location of the moist and semi-deciduous forests from which taxa such as Macaranga, Celtis, Olea capensis-type, Allophylus, Holoptelea grandis, Myrsine africana, Cassia-type, Embelia and Diospyros originate, even during the wettest periods recorded at Lake Chibwera. During dry episodes, more limited stream discharge from the eastern escarpment further reduced the visibility of these taxa in the Chibwera pollen assemblages. The comparatively higher percentages and strong climate response of Acalypha and Phoenix reclinata indicate that decadal variation in climatic moisture balance nevertheless caused significant changes in the prevalence of wooded savannah and riparian forest stands, beyond what can be explained by changes in stream input.

\section{Conclusions}

Combination of a high-resolution pollen record with modern pollen-assemblage data from reference sites spanning the modern-day regional grassland-forest transition of western Uganda permitted tracing local vegetation response to decade-scale climatic moisture-balance variation in a natural landscape of East African savannah. We find that the landscape surrounding Lake Chibwera in Queen Elizabeth National Park has been an open wooded savannah throughout the past 200 years, with historical rainfall variability exerting relatively modest effects on local tree cover (mostly the abundance of Acacia and Ficus) and the prevalence of damp soil areas (reflected in the abundance of Phoenix and Acalypha). Enhanced pollen input via an upland stream seems to be partly responsible for the strong apparent expansion of true forest trees during wet episodes. Hence, isolation of the truly local vegetation response will require palynological investigation of a savannah site with similarly continuous deposition but limited hydrological sensitivity compared to Lake Chibwera. On the positive side, the influence of pollen from exotic trees and other cultural indicators failed to mask the signature of natural vegetation dynamics in this site's pollen record.

Acknowledgements. Financial support for this study was provided by the Science for a Sustainable Development program of the Belgian Federal Science Policy (project SD/BD/03 CLANIMAE, 2007-2011). Fieldwork was conducted under Uganda National Council of Science and Technology permits EC540 and NS 162 and Uganda Wildlife Authority permit TBDP/RES/50), with additional sponsoring by Ghent University and the Research Foundation-Flanders (FWO Vlaanderen). We thank Bob Rumes, Pierre-Denis Plisnier, Christine Cocquyt and Julie Lebrun for assistance in the 2008 fieldwork, Annemarie Philip (Institute for Biodiversity and Ecosystem dynamics, University of Amsterdam) for sample preparation, Andreas Hemp and Geert van der Plas for discussion, and Mike Creutz and Aynalem Degefa for help with drafting the figures.

Edited by: J. Guiot

\section{References}

Andrua, H. J.: Tropical secondary forest management in Africa: Reality and perpectives, Uganda, Country paper, Ministry of Water, Lands, and Environment, Kampala, available at: http://www.fao. org/DOCREP/006/J0628E/J0628E65.htm, last access: 14 October 2014, 2002.

Bergonzini, L., Richard, Y., Petit, L., and Camberlin, P.: Zonal circulations over the Indian and Pacific oceans and the level of lakes Victoria and Tanganyika, Int. J. Climatol., 24, 1613-1624, 2004.

Bessems, I., Verschuren, D., Russell, J. M., Hus, J., Mees, F., and Cumming, B. F.: Palaeolimnological evidence for widespread late 18th century drought across equatorial East Africa, Palaeogeogr. Palaeocl., 259, 107-120, 2008. 
Blaauw, M.: Methods and code for "classical" age-modelling of radiocarbon sequences, Quat. Geochronol., 5, 512-518, 2010.

Broström, A., Sugita, S., and Gaillard, M.-J.: Pollen productivity estimates for the reconstruction of past vegetation cover in the cultural landscape of southern Sweden, Holocene, 14, 368-381, 2004.

Byaruhanga, A., Kasoma, P., and Pomeroy, D.: Important bird areas in Uganda, Royal society for the protection of birds. Nature Uganda, The East African Natural History Society, Kampala, 2001.

De Cort, G., Bessems, I., Keppens, E., Mees, F., Cumming, B., and Verschuren, D.: Late-Holocene and recent hydroclimatic variability in the central Kenya Rift Valley: the sediment record of hypersaline lakes Bogoria, Nakuru and Elementeita, Palaeogeogr. Palaeocl., 388, 69-80, 2013.

de Filippo, C., Bostoen, K., Stoneking, M., and Pakendorf, B.: Bringing together linguistic and genetic evidence to test the Bantu expansion, P. R. Soc. B., 279, 3256-3263, 2012.

Drescher-Schneider, R., de Beaulieu, J., Magny, M., WalterSimonnet, A., Bossuet, G., Millet, L., Brugiapaglia, E., and Drescher, A.: Vegetation history, climate and human impact over the last 15,000 years at Lago dell'Accesa (Tuscany, Central Italy), Veg. Hist. Archaeobot., 16, 279-299, 2007.

Duffin, K. I. and Bunting, M. J.: Relative pollen productivity and fall speed estimates for southern African savanna taxa, Veg. Hist. Arcaeobot., 17, 507-525, 2008.

Faegri, K., Kaland, P. E., and Krzywinski, K.: Textbook of Pollen Analysis, 4th Edn., John Wiley and sons Ltd, Chichester, 1989.

Flohn, H.: East African rains of 1961/62 and the abrupt change of White Nile discharge, Palaeoecology of Africa, 18, 3-18, 1987.

Friis, I.: Urticaceae, in: Flora of tropical East Africa, edited by: Polhill, R. M., Balkema, Rotterdam, 1-64, 1989.

Gelorini, V., Ssemmanda, I., and Verschuren, D.: Validation of nonpollen palynomorphs as paleoenvironmental indicators in tropical Africa: contrasting 200-year paleolimnological records of climate change and human impact, Rev. Palaeobot. Palyno., 186, 90-101, 2012a.

Gelorini, V., Verbeken, A., Lens, L., Eggermont, H., Odgaard, B., and Verschuren, D.: Effects of land use on the fungal spore richness in small crater-lake basins of western Uganda, Fungal Divers., 55, 125-142, 2012b.

Gelorini, V. and Verschuren, D.: Historical climate-humanecosystem interaction in East Africa: a review, Afr. J. Ecol., 51, 409-421, 2012.

Grimm, E. C.: CONISS: a FORTRAN 77 program for stratigraphically constrained cluster analysis by the method of incremental sum of squares, Comput. Geosci., 13, 13-35, 1987.

Grimm, E. C.: TILIA 1.7.16, Illinois State Museum, Springfield, available at: http://intra.museum.state.il.us/pub/grimm/tilia, last access: 14 October 2014, 2011.

Hemp, A.: Vegetation of Kilimanjaro: hidden endemics and missing bamboo, Afr. J. Ecol., 44, 305-328, 2006.

Jackson, S. T.: Pollen source area and representation in small lakes of the northeastern United States, Rev. Palaeobot. Palyno., 63, 53-76, 1990.

Jacobson Jr., G. L. and Bradshaw, R. H. W.: The selection of sites for paleovegetational studies, Quaternary Res., 16, 80-96, 1981.

Killick, D.: Cairo to Cape: the spread of metallurgy through eastern and southern Africa, J. World Prehist., 22, 399-414, 2009.
Kirabo, A., Byakagaba, P., Buyinza, M., and Namaalwa, J.: Agroforestry as a land conflict management strategy in western Uganda, Environmental Research Journal, 5, 18-24, 2011.

Krüger, O. and Johnson, D.: Bird communities in Kyambura Game Reserve, southwest Uganda, Ibis, 138, 564-567, 1996.

Lamb, H., Darbyshire, I., and Verschuren, D.: Vegetation response to rainfall variation and human impact in central Kenya during the past 1100 years, Holocene, 13, 285-292, 2003.

Langdale-Brown, I., Osmaston, H. A., and Wilson, J. G.: The vegetation of Uganda and its bearing on land-use, Uganda Government Printer, Entebbe, 1964.

Macmillan Uganda: Secondary school atlas, Macmillan Publishers, Kampala, 2004.

Marchant, R. and Taylor, D.: Dynamics of montane forest in central Africa during the late Holocene: a pollen-based record from western Uganda, Holocene, 8, 375-381, 1998.

Mathias, I. and Giesecke, T.: Insights into pollen source area, transport and deposition from modern pollen accumulation rates in lake sediments, Quaternary Sci. Rev., 87, 12-23, 2004.

Mills, K., Ryves, D. B., Anderson, N. J., Bryant, C. L., and Tyler, J. J.: Expressions of climate perturbations in western Ugandan crater lake sediment records during the last 1000 years, Clim. Past, 10, 1581-1601, doi:10.5194/cp-10-1581-2014, 2014.

Moore, P. D., Webb, J. A., and Collinson, M. E.: Pollen analysis, 2nd Edn., Blackwell Scientific Publications, Oxford, 1991.

Mutai, C. C. and Ward, M. N.: East African rainfall and the tropical circulation/convection on intraseasonal to interannual timescales, J. Climate, 13, 3915-3939, 2000.

National Biomass Study: Uganda land cover stratification (vegetation) with districts, counties and protected areas, Government of Uganda, Ministry of Natural Resources, Forestry Department, 1996.

Nicholson, S. E.: A review of climate dynamics and climate variability in eastern Africa, in: The Limnology, Climatology and Paleoclimatology of the East African Lakes, edited by: Johnson, T. C. and Odada, E. O., Gordon and Breach, Amsterdam, 25-56, 1996.

Nicholson, S. E.: Historical fluctuations of Lake Victoria and other lakes in the northern Rift Valley of East Africa, in: Environmental change and response in East African lakes edited by: Lehman, J. T., Kluwer, Dordrecht, 7-35, 1998.

Nicholson, S. E.: A semi-quantitative, regional precipitation data set for studying african climates of the nineteenth century, Part I. Overview of the data set, Climatic Change, 50, 317-353, 2001.

Nicholson, S. E. and Yin, X.: Rainfall conditions in equatorial East Africa during the nineteenth century as inferred from the record of Lake Victoria, Climatic Change, 48, 387-398, 2001.

Nicholson, S. E., Yin, X. G., and Ba, M. B.: On the feasibility of using a lake water balance model to infer rainfall: an example from Lake Victoria, Hydrolog. Sci. J., 45, 75-95, 2000.

Nicholson, S. E., Klotter, D., and Dezfuli, A. K.: Spatial reconstruction of semi-quantitative precipitation fields over Africa during the nineteenth century from documentary evidence and gauge data, Quaternary Res., 78, 13-23, 2012.

Piper, B. S., Plinston, D. T., and Sutcliffe, J. V.: The water balance of Lake Victoria, Hydrolog. Sci. J., 31, 25-38, 1986.

Quantum GIS Development Team: Quantum GIS Geographic Information System, Open Source Geospatial Foundation Project, 
available at: http://qgis.osgeo.org, last access: 14 October 2014, 1991.

Reid, A.: Cattle, identity and genocide in the African Great Lakes region, Archaeology International, 4, 35-38, 2000.

Robertshaw, P. and Taylor, D.: Climate change and the rise of political complexity in western Uganda, J. Afr. Hist., 41, 1-28, 2000.

Russell, J. M. and Johnson, T. C.: A high-resolution geochemical record from Lake Edward, Uganda Congo and the timing and causes of tropical African drought during the Late Holocene, Quaternary Sci. Rev., 24, 1375-1389, 2005.

Russell, J. M. and Johnson, T. C.: Little Ice Age Drought in Equatorial Africa: ITCZ migrations and ENSO variability, Geology, 35, 21-24, 2007.

Russell, J. M., Verschuren, D., and Eggermont, H.: Spatial complexity of "Little Ice Age" climate in East Africa: sedimentary records from two crater lake basins in western Uganda, Holocene, 17, 183-193, 2007.

Russell, J. M., McCoy, S. J., Verschuren, D., Bessems, I., and Huang, Y.: Human impacts, climate change, and aquatic ecosystem response during the past $2000 \mathrm{yr}$ at lake Wandakara, Uganda, Quaternary Res., 72, 315-324, 2009.

Ryves, D. B., Mills, K., Bennike, O., Broderson, K. P., Lamb, A. L., Leng, M. J., Russell, J. M., and Ssemmanda, I.: Environmental change over the last millennium recorded in two contrasting crater lakes in western Uganda, eastern Africa (Lakes Kasenda and Wandakara), Quaternary Sci. Rev., 30, 555-569, 2011.

Ssemmanda, I., Ryves, D. B., Bennike, O., and Appleby, P. G.: Vegetation history in western Uganda during the last 1200 years: a sediment-based reconstruction from two crater lakes, Holocene, 15, 119-132, 2005.

Stager, J. C., Ryves, D., Cumming, B. F., Meeker, L. D., and Beer, J.: Solar variability and the levels of Lake Victoria, East Africa, during the last millennium, J. Paleolimnol., 33, 243-251, 2005.

Sugita, S.: POLLSCAPE model: simulation approach for pollen representation of vegetation and land cover, Encyclopedia of Quaternary Science, 2nd Edn., 3, 871-879, 2013.

Taylor, D., Marchant, R. M., and Robertshaw, P.: A sediment-based history of medium-altitude forest in central Africa: a record from Kabata Swamp, Ndale volcanic field, Uganda, J. Ecol., 87, 303-315, 1999.

Taylor, D., Lane, P. J., Muiruri, V., Ruttledge, A., Mckeever, G. R., Nolan, T., Kenny, P., and Goodhue, R.: Mid- to late-Holocene vegetation dynamics on the Laikipia Plateau, Kenya, Holocene, 15, 837-846, 2005.
Verschuren, D.: A lightweight extruder for accurate sectioning of soft-bottom lake sediment cores in the field, Limnol. Oceanogr., 38, 1796-1802, 1993.

Verschuren, D.: Influence of depth and mixing regime on sedimentation in a fluctuating tropical soda lake, Limnol. Oceanogr., 44, 1103-1113, 1999.

Verschuren, D.: Reconstructing fluctuations of a shallow East African lake during the past 1800 years from sediment stratigraphy in a submerged crater basin, J. Paleolimnol. 25, 297-311, 2001.

Verschuren, D.: Decadal and century-scale climate variability in tropical Africa during the past 2000 years, in: Past climate variability through Europe and Africa, edited by: Batterbee, R. W., Gasse, F., and Stickley, C. E., Springer-Verlag, Berlin, 139-158, 2004.

Verschuren, D., Laird, K. R., and Cumming, B. F.: Rainfall and drought in equatorial east Africa during the past 1100 years, Nature, 403, 410-414, 2000.

Vincens, A., Ssemmanda, I., Roux, M., and Jolly, D.: Study of the modern pollen rain in western Uganda with a numerical approach, Rev. Palaeobot. Palyno., 96, 145-168, 1997.

Vincens, A., Williamson, D., Thevenon, F., Taieb, M., Buchet, G., Decobert, M., and Thouveny, N.: Pollen-based vegetation changes in southern Tanzania during the last 4200 years: climate change and/or human impact, Palaeogeogr. Palaeocl., 198, 321-334, 2003.

Vincens, A., Bremond, L., Brewer, S., Buchet, G., and Dussouillez, P.: Modern pollen-based biome reconstructions in East Africa expanded to southern Tanzania, Rev. Palaeobot. Palyno., 140, 187-212, 2006.

Vincens, A., Lezine, A.-M., Buchet, G., Lewden, D., Le Thomas, A., and contributors: African pollen database inventory of tree and shrub pollen types, Rev. Palaeobot. Palyno., 145, 135-141, 2007.

White, F.: The vegetation of Africa: a descriptive memoir to accompany the UNESCO/AETFAT/UNSO vegetation map of Africa, Natural Resources Research, 20, 1-356, 1983.

Wright Jr., H. E.: Coring of soft lake sediments, Boreas, 9, 107-114, 1980. 